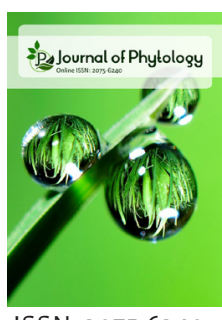

ISSN: $2075-6240$

\title{
Biodiversity of some fig cultivars in Southern Syria
}

\author{
Sahara Abo Amin*, Faisal Hamed', Seba Sarhan², Nashaat Abo Tafish³ \\ ${ }^{1}$ Department of Horticultural Sciences, Faculty of Agriculture, Damascus University, Syria, ${ }^{2}$ Department of Basic \\ Sciences, Faculty of Agriculture, Damascus University, Damascus, Syria, ${ }^{3}$ General Authority for Agricultural \\ Scientific Research, Swaida, Syria
}

\begin{abstract}
Genetic diversity of fourteen cultivars of figs (Ficus carica L.) growing in Swaida governorate which is located in the south region of Syria were investigated using (Simple Sequence Repeats) SSRs technique. The four cultivars were collected from local fields without any scientific taxonomy and the farmers did not classify them properly. Eight pairs of SSRs markers were used depending on their ability to separate between fig cultivars used in previous studies, six pairs of them gave amplified products while MFC3 and MFC6 primers did not give any amplification. A total of 17 alleles were detected at six SSRs loci. The alleles number per locus ranged from 2 to 4 with an average of 2.83 alleles/locus. The observed heterozygosity (Ho) was 0.33 , while the expected heterozygosity (He) was 0.17 . The mean value of genetic similarity was 0.69 where fig cultivars have separated into two clusters in Cluster Analysis, which confirms a significant genetic similarity between most of the cultivars. MFCl and MFC2 loci gave about 0.67 and 0.61 PIC (Polymorphism Information Content) values respectively, which confirm their ability to study the genetic diversity of fig cultivars more than other loci. F1 and F2 cultivars greatly affect the quality of the fruits as paternity traits as Caprifigs. Tammozi cultivar has low values of its genetic similarity with the rest of the cultivars the Generally, the challenges in this study were in characterizing unrecognized fig cultivars in southern Syria to distinguish between them as they were not certified in the agriculture ministry in Syria of the present study able the SSR markers differentiated the fig cultivars in Syria.
\end{abstract}

Keywords: Simple Sequence Repeats (SSRs), Molecular Classification, Figs, PCR.

*Corresponding Author

Sahara Abo Amin

E-mail: saharaaboamin@gmail. com et al., 2010). The extensive and indiscriminate exploitation of these genetic resources led to a deterioration in natural resources and a severe shortage of biodiversity in the region, which necessitated the preservation, characterization, classification, and multiplication of these resources to use them in future breeding programs for Syrian fig cultivars. This work aimed to study the genetic diversity of fourteen cultivars of figs (Ficus carica L.) growing in Swaida governorate in southern Syria using SSRs (Simple Sequence Repeats) technique. The importance of the varieties used lies in being the most productive qualitatively and quantitatively, as many unnamed numerous genotypes are present in the region likewise other regional studies in turkey (Akin et al., 2020). Hence, it is imperative to pay particular attention to endangered and rare cultivars (Debbabi et al., 2021) for characterization.

\section{MATERIALS AND METHODS}

This study was carried out in the Department of Horticultural Sciences and the Laboratories of Biotechnology at the Faculty of Agriculture, Damascus University, in 2019 and 2020.

Copyright: $\odot$ The authors. This article is open access and licensed under the terms of the Creative Commons Attribution License (http://creativecommons.org/licenses/by/4.0/) which permits unrestricted, use, distribution and reproduction in any medium, or format for any purpose, even commercially provided the work is properly cited. Attribution - You must give appropriate credit, provide a link to the license, and indicate if changes were made. 


\section{Plant material}

Ten local cultivars of figs (Figures 1-14) obtained from the gene bank collection of the General Commission of Scientific Agricultural Research (site Haut), and four wild-growing cultivars in the Areeka site were investigated in this study (Table 1)

\section{Molecular study}

Fresh leaves of fig 3 to 4-week-old growths, free of pathological and insect injuries, were collected at the end of April from one representative tree of each cultivar. The samples were washed with distilled water, placed in transparent plastic bags, and stored at $-80 \mathrm{C}^{\circ}$ until use.

\section{DNA extraction}

DNA was extracted fromleaves using the cetyltrimethylammonium bromide (CTAB) method described by Chatti et al. (2010). The quantity of the extracted gDNA was determined by measuring the UV absorbance at 260 and $280 \mathrm{~nm}$ using a spectrophotometer. The quality of extracted DNA was determined by gel electrophoresis on ethidium bromide-stained $1 \%$ agarose. DNA was then used as a template for subsequent amplification using PCR.

\section{Simple Sequence Repeats (SSRs)}

\section{DNA Amplification}

Eight pairs of SSRs markers were selected because of their high polymorphism in the fig family (Khadari et al., 2001). The appropriate annealing temperature for each pair of primers was calculated, where temperatures varied by the number of nucleotides and the GC\% (Table 2, Khadari et al., 2001). The PCR reaction was performed in $25 \mu \mathrm{l}$ final volumes with a mixture of $50 \mathrm{ng}$ of genomic DNA, 1X Taq buffer, $0.32 \mu \mathrm{M}$ dNTP, $1.5 \mathrm{mM} \mathrm{MgCl}_{2}, 4 \mu \mathrm{M}$ of each forward and reverse primers and $0.2 \mathrm{U} / \mu \mathrm{l} \mathrm{Taq}$ DNA polymerase supplemented with water to $25 \mu$. The PCR conditions were as follows: pre-denaturation at $95^{\circ} \mathrm{C}$ for $5 \mathrm{~min}$; denaturation at $95^{\circ} \mathrm{C}$ for $1 \mathrm{~min}$, annealing

Table 1: Codes and Names of fig cultivars investigated in this study

\begin{tabular}{ll}
\hline Code & Name \\
\hline 1 & $F(4)$ Areeka \\
2 & $F(1)$ Areeka \\
3 & $F(2)$ Areeka \\
4 & $F(3)$ Areeka \\
5 & Small Bokrati \\
6 & Bokrati \\
7 & Moloki \\
8 & Sokari \\
9 & Dwashi \\
10 & Bechari \\
11 & Karima \\
12 & Bragi \\
13 & Swaidi \\
14 & Tammozi \\
\hline
\end{tabular}

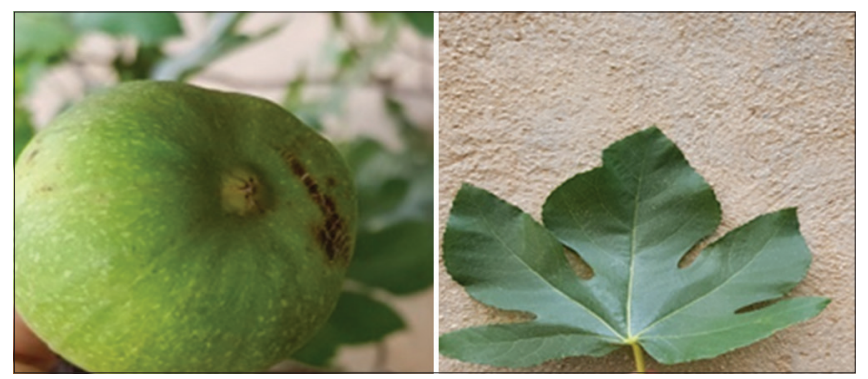

Figure 1: F2 cultivar fruit and leaf shape

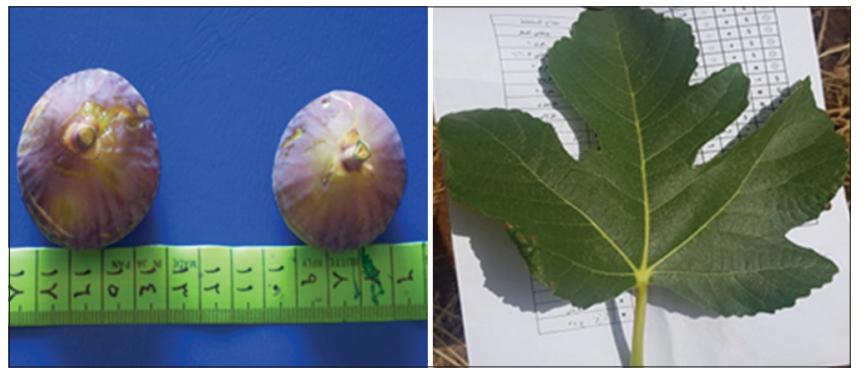

Figure 2: Karima fruit and leaf shape
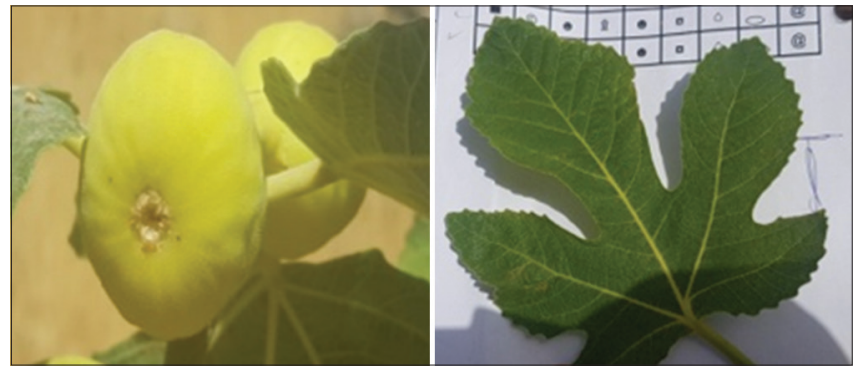

Figure 3: Bechari fruit and leaf shape
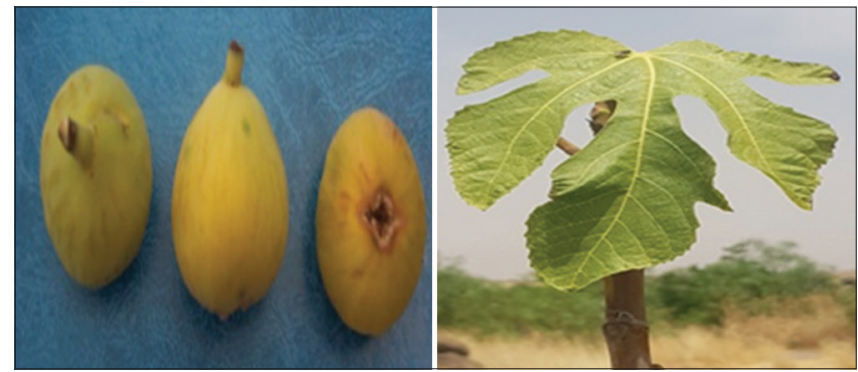

Figure 4: Moloki fruit and leaf shape

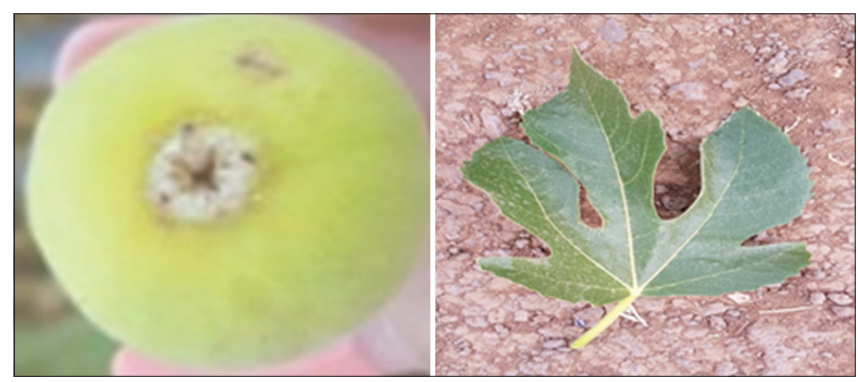

Figure 5: F3 cultivar fruit and leaf shape 


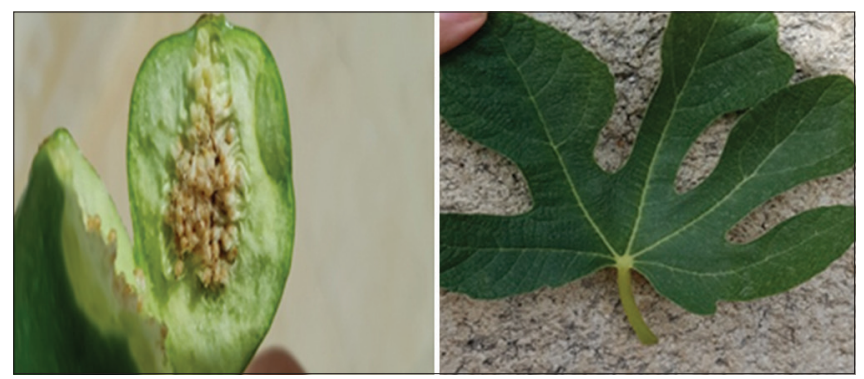

Figure 6: F1 cultivar fruit and leaf shape

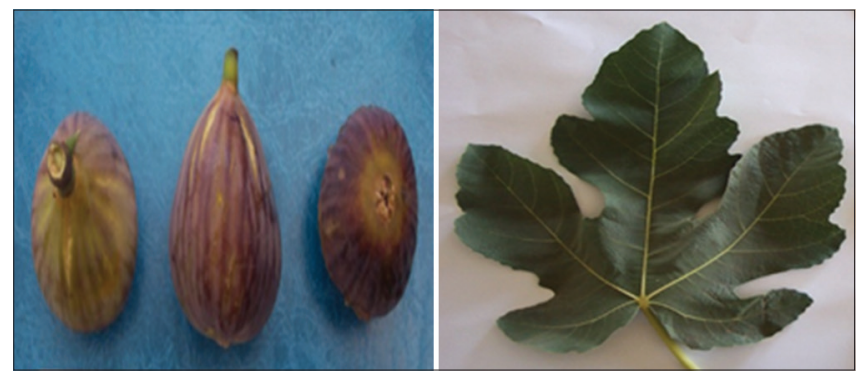

Figure 7: Bragi cultivar fruit and leaf shape

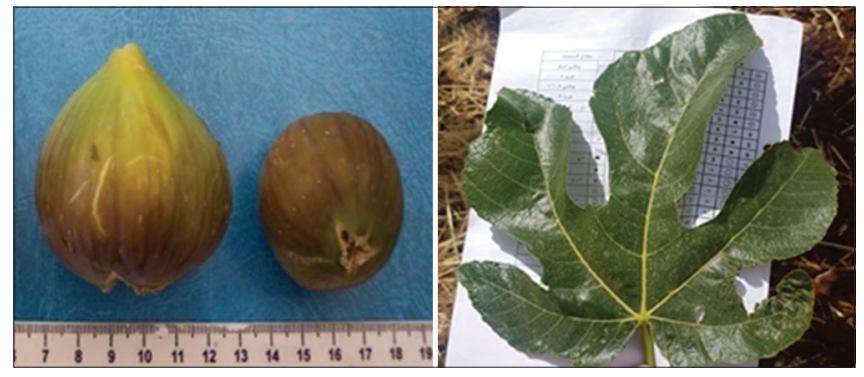

Figure 8: Swaidi cultivar fruit and leaf shape

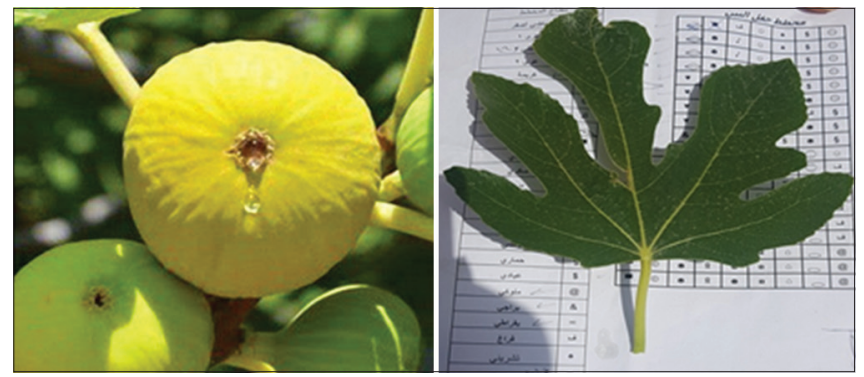

Figure 9: Sokari cultivar fruit and leaf shape

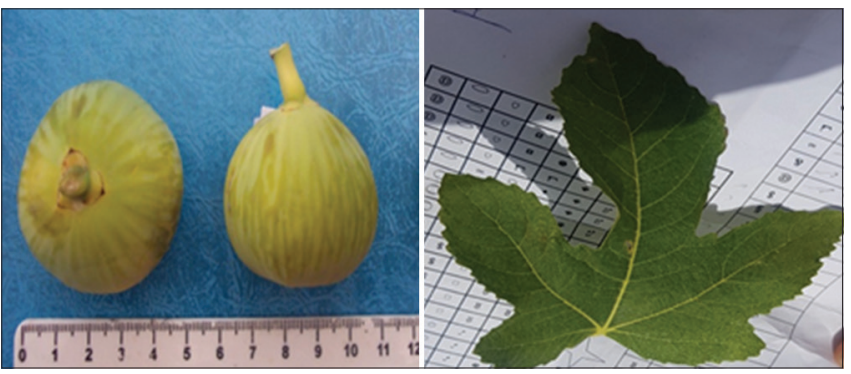

Figure 10: Dwashi cultivar fruit and leaf shape

at an appropriate temperature for each primer for $1 \mathrm{~min}$, and extension at $72{ }^{\circ} \mathrm{C}$ for $1 \mathrm{~min}$ and final extension at $72{ }^{\circ} \mathrm{C}$ for

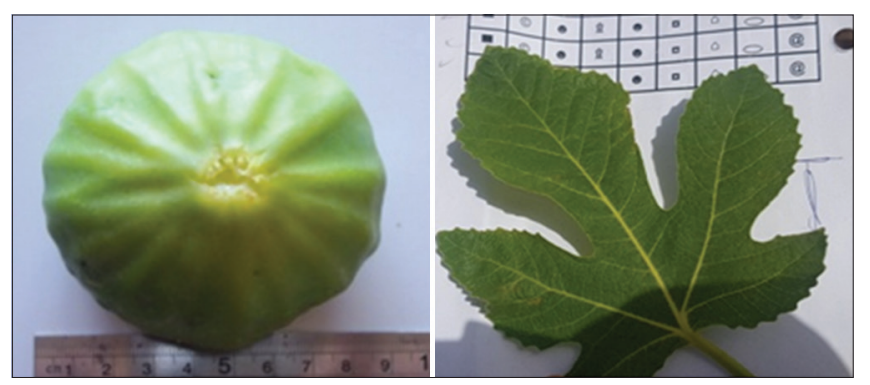

Figure 11: Tammozi cultivar fruit and leaf shape

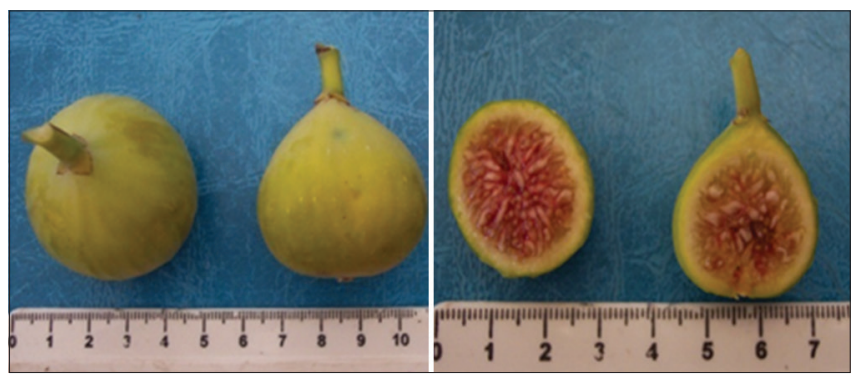

Figure 12: Bokrati cultivar fruit shape

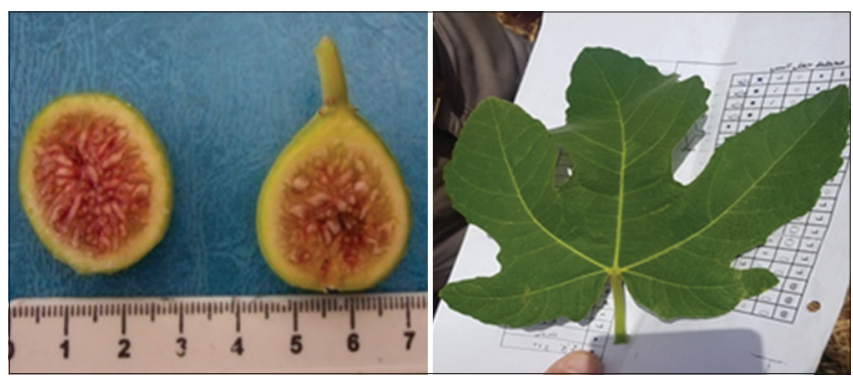

Figure 13: Small Bokrati cultivar fruit and leaf shape

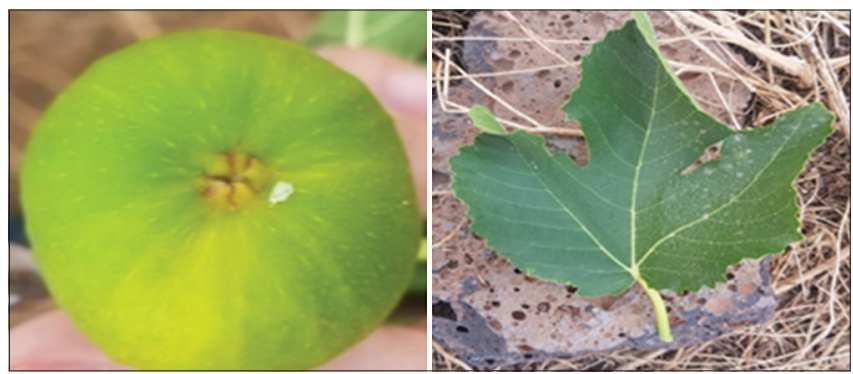

Figure 14: F4 cultivar fruit and leaf shape

$10 \mathrm{~min}$. Amplified products were analyzed using $3 \%$ agarose gel electrophoresis, and visualized under a UV transilluminator.

\section{Statistical analysis}

The degree of genetic similarity was determined by calculating the convergence ratio matrix and drawing the genetic similarity tree. Any presented allele was encoded by number 1, while alleles that did not present were encoded by 0 . The molecular weights of DNA bands were read using the gel Quant program (ver 1.8.2) (Lazar, 2010). Then, using the convergence ratio matrix (Dice, 1945) by Paleontological Statistics program (ver. 1.67), the genetic 
Table 2. The nucleotide sequence of SSR primers GC \% and the number of repeats per primer (frequency) with the appropriate annealing temperature for each pair

\begin{tabular}{|c|c|c|c|c|c|}
\hline Primer & Band Size & The nucleotide sequence & GC\% & frequency & $\begin{array}{c}\text { Annealing } \\
\text { temperature (c) }\end{array}$ \\
\hline $\mathrm{MFCl}$ & 192 & $\begin{array}{l}\text { ACTAGACTGAAAAAACATTGC } \\
\text { TGAGATTGAAAGGAAACGAG }\end{array}$ & 36.5 & {$[\mathrm{CT}]_{13}$} & 55 \\
\hline MFC2 & 172 & $\begin{array}{l}\text { GCTTCCGATGCTGCTCTTA } \\
\text { TCGGAGACTTTTGTTCAAT }\end{array}$ & 44.7 & {$[\mathrm{AC}]_{18}[\mathrm{ATT}]_{7}$} & 55 \\
\hline MFC3 & 136 & $\begin{array}{l}\text { GATATTTTCATGTTTAGTTTG } \\
\text { GAGGATAGACCAACAACAAC }\end{array}$ & 34.1 & $\begin{array}{c}{[\mathrm{AC}]_{15} \mathrm{TC}[\mathrm{AC}]_{8}} \\
{[\mathrm{ATT}]_{7}}\end{array}$ & 55 \\
\hline MFC4 & 218 & $\begin{array}{l}\text { CCAAACTTTTAGATACAACTT } \\
\text { TTTCTCAACATATTAACAGG }\end{array}$ & 29.2 & {$[\mathrm{ATT}]_{4}[\mathrm{AC}]_{11}$} & 55 \\
\hline MFC5 & 140 & $\begin{array}{l}\text { ACCAATCCAAATAATAATCC } \\
\text { ACACGCTTACTAGAATTACC }\end{array}$ & 35 & {$[G A]_{13}$} & 50 \\
\hline MFC6 & 313 & $\begin{array}{l}\text { AGGCTACTTCAGTGCTACA } \\
\text { GCCATAAGTAATAAAAACC }\end{array}$ & 39.4 & {$[\mathrm{TAA}]_{3,}[\mathrm{GTT}]_{8}$} & 50 \\
\hline $\mathrm{MFC7}$ & 150 & $\begin{array}{l}\text { CACAATCAAAATAGTTACCG } \\
\text { AGCGAAGACAGTTACAAAGC }\end{array}$ & 39 & {$[A G]_{11}$} & 50 \\
\hline MFC8 & 179 & $\begin{array}{l}\text { GTGGCGTCGTCTCTAATAAT } \\
\text { TATTCTATGCTGTCTTATGTCA }\end{array}$ & 38 & $\begin{array}{c}{[\mathrm{CA}]_{9} \mathrm{TA}[\mathrm{CA}]_{14}} \\
{[\mathrm{TA}]_{6}}\end{array}$ & 50 \\
\hline
\end{tabular}

similarity tree between cultivars was drawn using the PAST statistical program (Hammer et al., 2001). The total number of alleles generated in each locus and the PIC (Polymorphic Information Content) were calculated according to Botstein (Botstein et al., 1980), also Expected heterozygosity (He) and observed heterozygosity (Ho) was calculated according to: $\mathrm{He}=1-$ $\sum$ Pi2 (Powell et al., 1996), Where Pi is the frequency of the allele in the I locus. Ho is the heterogeneous proportion of individuals, calculated using the Gene Alex program (Peakall \& Smouse, 2012).

\section{RESULTS AND DISCUSSION}

\section{Polymorphism among fig cultivars}

SSR polymorphism results from the difference in the number of repetitive units in the loci of simple sequence repeat when using pairs of primers designed according to the area around the locus, thus it is determined by the amplification products lengths in the polymerase chain reaction PCR. Six of the eight pairs of primers used on the fig cultivars gave amplified products in the polymerase chain reaction, while MFC3 and MFC6 primers did not give any amplification.

A total of 17 alleles were detected at six SSRs loci in this study while in another (Sadder et al., 2021) study a total of 124 alleles were detected with 310 accessions and 14 SSR loci. The allele number per locus ranged from 2 to 4 . In other studies, 3.59 alleles per locus were detected (Boudchicha et al., 2018). Knap et al. (2001) showed that the detected allele number per locus ranged from 2 to 5 . In contrast, the allele number per locus was higher in other studies, where it was ranged from 3 to 6 (Millar \& Westfall, 1992) and from 4 to 9 alleles per locus with 194 breeds due to the greater number of SSR loci (Saddoud et al., 2007). The average number of alleles in our study was lower than that showed by Giraldo et al. (2005) with 3 alleles/ locus. Ahmed et al. (2015) used 17 SSR loci to characterize 71 cultivated and wild Tunisian fig-trees revealing a total of 74 alleles. 91 alleles were detected with an average of 13 alleles per locus (Ganopoulos et al., 2015). 12 local cultivars and two caprifigs, in addition to 15 reference samples have been fingerprinted using 21 SSR markers, a total of 77 alleles were detected (Perez-Jiménez et al., 2012).

This relative decrease in the average number of alleles in our study compared to the previous studies may be due to the same origins of cultivars, and to the few numbers of strains and primers used. The difference in the effectiveness of each locus is likely to be due to the number of cultivars, which reflects a greater chance to find more alleles as the number of polymorphic patterns increases. A total of 20 polymorphic patterns between the cultivars were identified, with $\mathrm{MFCl}$ and $\mathrm{MFC} 2$ giving the highest number of polymorphic patterns ( 5 patterns) (Figures 15 and 16), followed by MFC7 (Figure 17), and the rest of the primers gave only two patterns of polymorphism (Figures 18 and 19) with an average of 3.17 (Table 3). The number of patterns that appeared in our study was lower than those patterns that appeared in Khadari et al. (2001) and Saddoud, 2007) studies, and that is due to the high number of samples studied in their studies in comparison to our study. The difference in the number of alleles per locus is explained by the structure of the repetitive units in it, so the variation is lower when the repetitive units in the locus are simple and short.

1-F4, 2-F1, 3-F2, 4-F3, 5- Small Bokrati, 6- Bokrati,7- Moloki, 8- Sokari, 9- Dwashi, 10-Bechari, 11-Karima, 12- Bragi, 13-Swaidi, 14- Tammozi

1-F4, 2-F1, 3-F2, 4-F3, 5- Small Bokrati, 6- Bokrati,7- Moloki, 8- Sokari, 9- Dwashi, 10-Bechari, 11- Karima, 12- Bragi, 13-Swaidi, 14- Tammozi

Ml Standard marker 50 bp. 1-F4, 2-F1, 3-F2, 4-F3, 5- Small Bokrati, 6- Bokrati,7- Moloki, 8- Sokari, 9- Dwashi, 10-Bechari, 11- Karima, 12- Bragi, 13-Swaidi, 14- Tammozi

1-F4, 2-F1, 3-F2, 4-F3, 5- Small Bokrati, 6- Bokrati,7- Moloki, 8- Sokari, 9- Dwashi, 10-Bechari, 11- Karima, 12- Bragi, 13-Swaidi, 14- Tammozi 


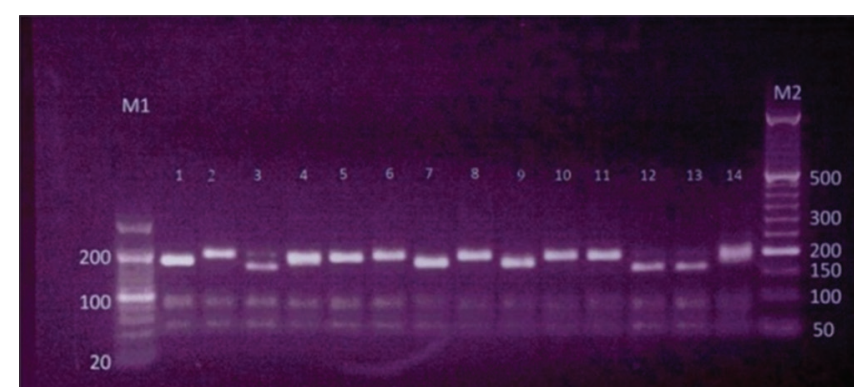

MFC1

Figure 15: DNA bands resulting from MFC1 amplification where the numbers 1-14 indicate fig cultivars codes, M1 Standard marker 20 bp, M2 Standard marker $50 \mathrm{bp}$

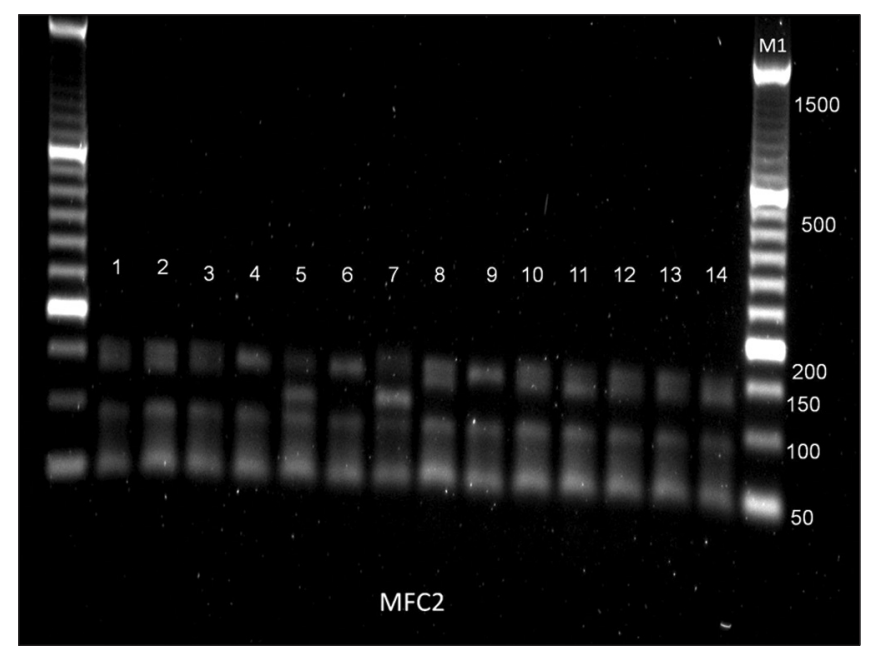

Figure 16: DNA bands resulting from MFC2 amplification where the numbers 1-14 indicate fig cultivars codes. M1 Standard marker 50 bp

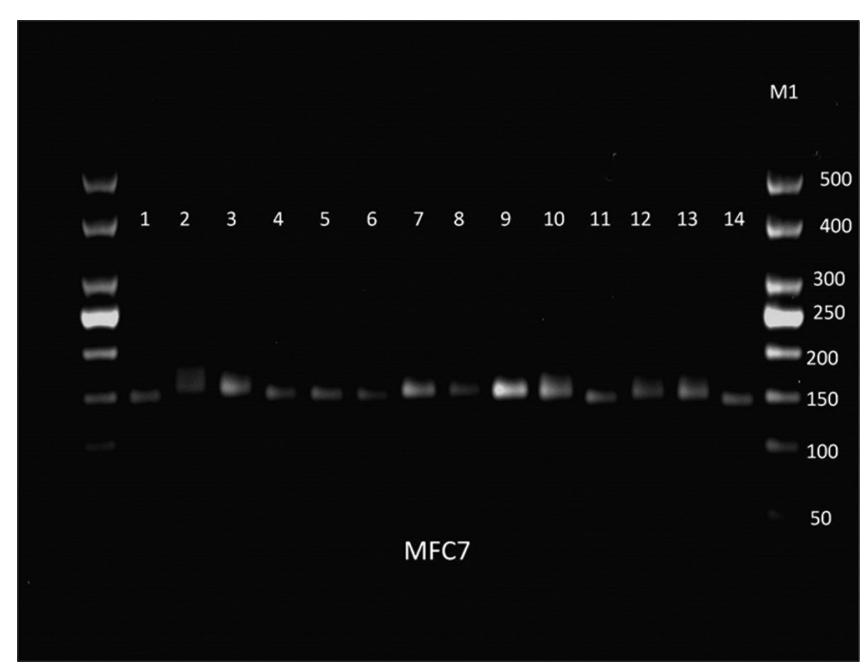

Figure 17: DNA bands resulting from MFC7 amplification where the numbers 1-14 indicate fig cultivars codes
In all the studied cultivars, the observed heterozygosity (mean $\mathrm{Ho}_{0}=0.33$ ) was higher than the expected heterozygosity (mean $\mathrm{He}=0.17$ ). In other studies, the expected heterozygosity ranged from 0.071 to 0.796 and the observed heterozygosity ranged between 0.071 and 1.0000 (Ali, 2019), while Ho ranged from 0.18 to 0.76 and He ranged between 0.24 and 0.81 (Eoman et al., 2017) meanwhile in (Sadder et al., 2021) study He and Ho values were 0.652 and 0.685 , respectively.

Six primers $(75 \%)$ of the total primers used were polymorphic. Polymorphism was lower in MFC4 and MFC8 (about 0.13), and that is maybe because the cultivars are from the same region. To determine the best loci for the cultivars characterization, primers were classified according to the number of polymorphic patterns, $\mathrm{MFCl}$ and $\mathrm{MFC} 2$ gave the highest number of patterns 5, while MFC7 gave 3 patterns and 3 alleles, the remaining loci resulted in 2 alleles and 2 patterns. The band's molecular weights are directly related to the primers' structures (Huang et al., 2002), so the calculation of PIC for each primer is an essential criterion indicating the ability of the primer to distinguish and show genetic

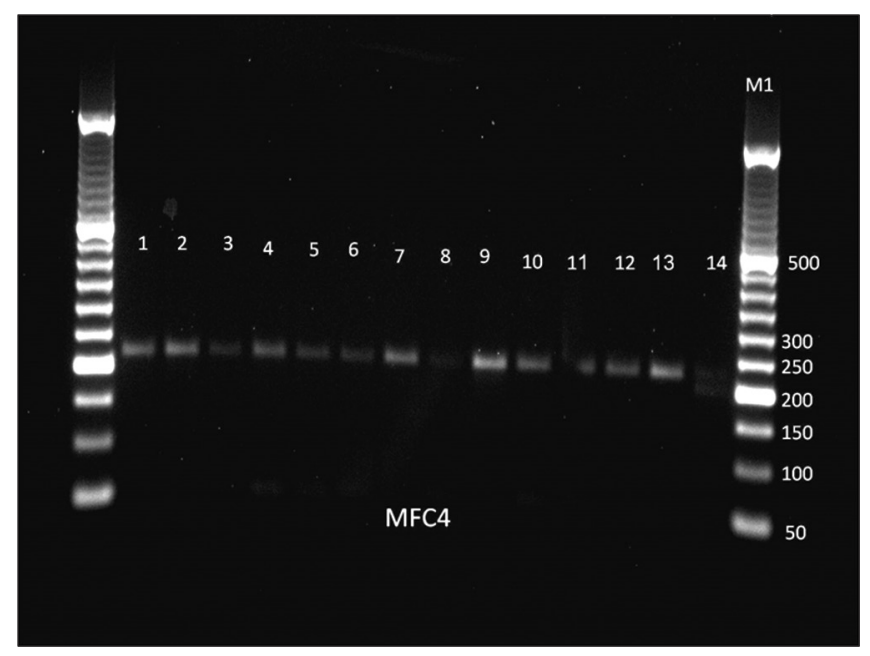

Figure 18: DNA bands resulting from MFC4 amplification where the numbers 1-14 indicate fig cultivars codes. M1 Standard marker 50 bp

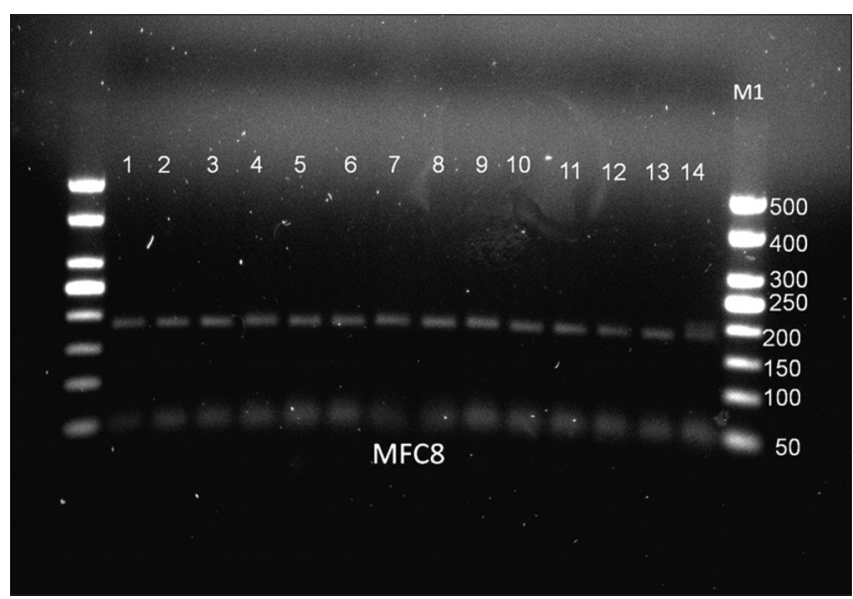

Figure 19: Unique band resulting from MFC8 primer in Tammozi cultivar, M standard marker 50bp 
variations between different cultivars, thus the closer the PIC value is to 1 , the greater the ability to distinguish and show genetic variations. In our work, the values of PIC were low to medium, ranging from 0.13 to 0.67 , (Table 3) while in other studies PIC ranged from 0.67 to 0.85 (Saddoud et al., 2011), which indicates that the loci of SSR in our study present a low to medium ability to distinguish the cultivars and show the genetic variation between them because the cultivars have the same origins, which in turn increases their homozygous characteristics. Based on the resulting $\mathrm{PIC}$ values, $\mathrm{MFCl}$ can be distinguished with the highest value of PIC 0.67 followed by MFC7 with a PIC value of 0.64 . Mafrica et al. (2015) showed that the mean PIC was 0.51 . The number of alleles detected in each cultivar ranged between 6 to 9, with the highest number in moloki and Tammozi cultivars

\section{Distinguish fig cultivars using unique bands}

Some of the SSR markers were able to distinguish unique bands in Tammozi cultivar such as (Figure 5) which has unique band in MFC8 primer with 205 bp molecular weight and another unique band appeared in $\mathrm{MFCl}$ primer with $200 \mathrm{bp}$.

1-F4, 2-F1, 3-F2, 4-F3, 5-Small Bokrati, 6- Bokrati,7-Moloki, 8- Sokari, 9- Dwashi, 10-Bechari, 11- Karima, 12- Bragi, 13-Swaidi, 14- Tammozi

\section{Genetic similarity between cultivars}

The degree of genetic similarity between cultivars was determined by the Dice coefficient (Table 4), where the highest degree of genetic similarity was between Bokrati, and F3 (1.00), and Bragi and Swaidi) 1.00), while the lowest genetic similarity was between Tammozi and F3, and between small Bokrati, Bokrati, and Dwashi (0.375). The mean value of genetic similarity was 0.69. Akin et al. (2020) showed genetic similarity between 0.24 and 0.90 which confirms a significant genetic convergence between most of the cultivars in our study, except Tammozi cultivar which revealed low similarity with the rest of the cultivars with an average similarity of 0.57 , lower than the general average of similarity and that is maybe due to the difference of origin. The results could not distinguish between Bokrati and F3 or between Bragi and Swaidi in any of the investigated loci, and that is maybe due to the high morphological similarity between them or because they differ by only one or few numbers of simple sequence repeats (Di Gaspero et al., 2000).

\section{UPGMA Cluster analysis of fig cultivars}

Cluster analysis divided cultivars into groups, reflecting the degree of genetic similarity among them. Generally, cultivars may be a group in a single group according to their geographical origin, or gender (Hormaza, 2002). The cultivars in this study were separated into two main groups (Figure 20) at a similarity level of 0.69 , and this distribution is supported by a $100 \%$ of reliability. In the second group B, F3 and Bokrati are incomplete symmetry at the level of $83 \%$ of reliability, and small Bokrati was associated with them at a 0.87 of similarity, Dwashi linked to bl subgroup at a $29 \%$ of reliability, and these results are agreement with previous studies in Kurdistan Region-Iraq

Table 3. Number of alleles resulting from primer pairs used in SSR ( $\mathrm{Na})$, Polymorphic patterns, polymorphic information content (PIC), and bands lengths (bp) for each primer pair

\begin{tabular}{lcccc}
\hline Primer name & Band lengths (bp) & polymorphic information content (PIC) & Polymorphic patterns & Number of alleles (Na) \\
\hline MFC1 & $170-200$ & 0.67 & 5 & 4 \\
MFC2 & $130-170$ & 0.61 & 5 & 2 \\
MFC4 & $200-230$ & 0.13 & 2 & 2 \\
MFC5 & $130-150$ & 0.49 & 3 & 2 \\
MFC7 & $150-170$ & 0.64 & 2 & 3 \\
MFC8 & $200-205$ & 0.13 & 3.17 & 2 \\
Mean & 175 & 0.45 & & 2.83 \\
\hline
\end{tabular}

Table 4. Genetic similarity degree between fig cultivars based on dice coefficient

\begin{tabular}{|c|c|c|c|c|c|c|c|c|c|c|c|c|c|c|}
\hline Cultivar & $\mathrm{F} 4$ & $\mathrm{Fl}$ & F2 & F3 & $\begin{array}{c}\text { Small } \\
\text { Bokrati }\end{array}$ & Bokrati & Moloki & sokari & dwashi & Bechari & karima & Bragi & Swaidi & Tammozi \\
\hline F4 & 1 & & & & & & & & & & & & & \\
\hline $\mathrm{Fl}$ & 0.750 & 1 & & & & & & & & & & & & \\
\hline F2 & 0.625 & 0.875 & 1 & & & & & & & & & & & \\
\hline F3 & 0.533 & 0.667 & 0.533 & 1 & & & & & & & & & & \\
\hline Small & 0.400 & 0.533 & 0.533 & 0.857 & 1 & & & & & & & & & \\
\hline \multicolumn{15}{|l|}{ Bokrati } \\
\hline Bokrati & 0.533 & 0.667 & 0.533 & 1 & 0.857 & 1 & & & & & & & & \\
\hline Moloki & 0.706 & 0.706 & 0.588 & 0.625 & 0.625 & 0.625 & 1 & & & & & & & \\
\hline Sokari & 0.571 & 0.714 & 0.714 & 0.769 & 0.769 & 0.769 & 0.400 & 1 & & & & & & \\
\hline Dwashi & 0.667 & 0.533 & 0.400 & 0.857 & 0.714 & 0.857 & 0.750 & 0.615 & 1 & & & & & \\
\hline Bechari & 0.667 & 0.800 & 0.800 & 0.714 & 0.714 & 0.714 & 0.500 & 0.923 & 0.571 & 1 & & & & \\
\hline Karima & 0.800 & 0.800 & 0.800 & 0.571 & 0.571 & 0.571 & 0.500 & 0.769 & 0.429 & 0.857 & 1 & & & \\
\hline Bragi & 0.667 & 0.800 & 0.933 & 0.429 & 0.429 & 0.429 & 0.625 & 0.615 & 0.429 & 0.714 & 0.714 & 1 & & \\
\hline Swaidi & 0.667 & 0.800 & 0.933 & 0.429 & 0.429 & 0.429 & 0.625 & 0.615 & 0.429 & 0.714 & 0.714 & 1 & 1 & \\
\hline Tammozi & 0.706 & 0.588 & 0.588 & 0.375 & 0.375 & 0.375 & 0.444 & 0.533 & 0.375 & 0.625 & 0.750 & 0.625 & 0.625 & 1 \\
\hline
\end{tabular}


(Hussien et al., 2020).Group A was divided into three subgroups, where Tammozi came associated in the highest hierarchical level with a similarity of 0.61 . The first subgroup al included F4 and moloki together at a similarity of 0.71 , while the second subgroup a 2 match Bragi and Swaidi at $56 \%$ of reliability, associated with $\mathrm{F} 2$ at $92 \%$ of similarity. Fl also came with them at 0.82 of similarity. The third subgroup a3 included Sokari and Bechari with Karima at 0.82 of similarity. In comparison with another study, UPGMA cluster analysis grouped caprifig accessions in three groups (Essid et al., 2015). High-reliability values within subgroups $(>0.60 \%)$ confirm that cultivars which came together are genetically similar. For example, the presence of Bragi and Swaidi at a similarity level of 1.00 match with F2 at a $56 \%$ of reliability, indicating their involvement in the same loci with minor differences.

According to the genetic similarity tree, groups of cultivars are associated with each other at the molecular level, as well as they can be described as very similar in their morphological characteristics. The high similarity of these cultivars indicates that it is necessary to analyze them using a greater number of SSR loci that are directly associated with genes responsible for quantity or quality characteristics, to separate each of them

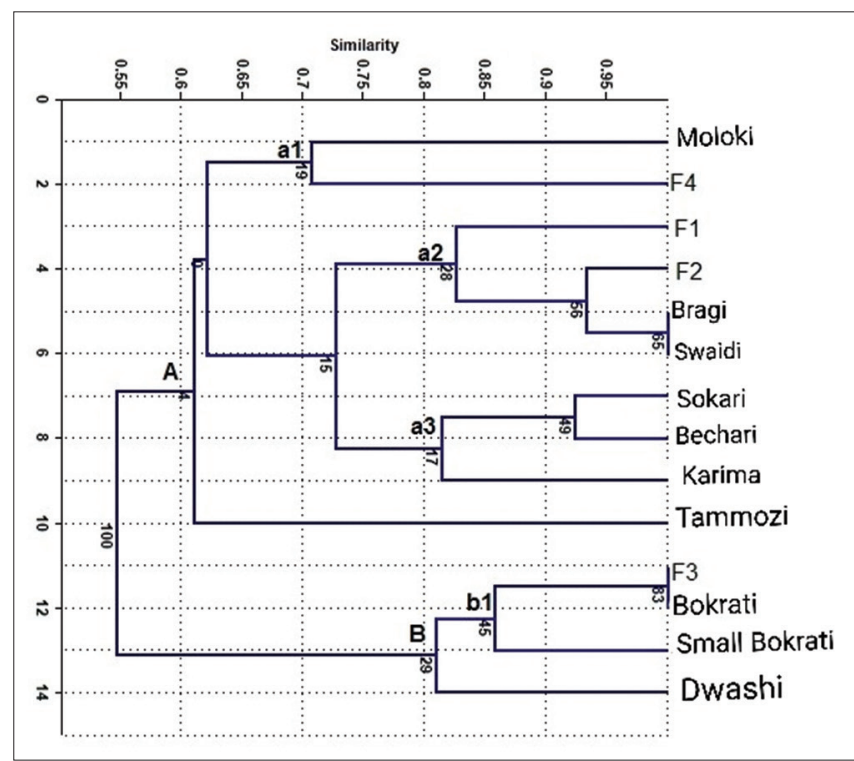

Figure 20: Cluster analysis of fig cultivars based on Dice coefficient

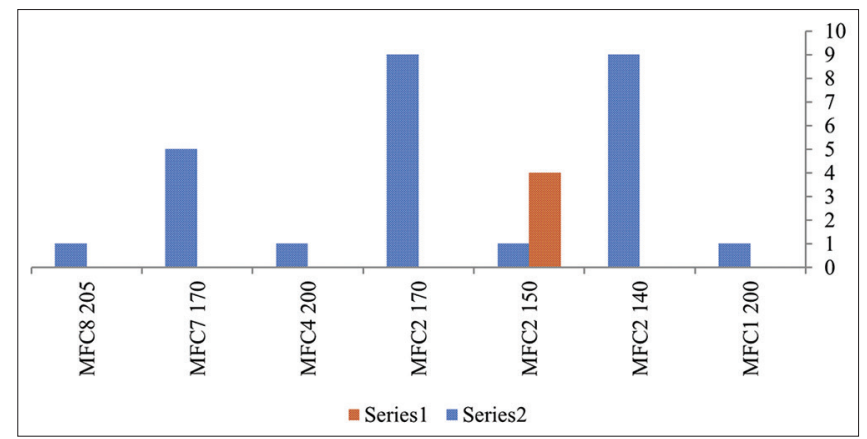

Figure 21: The distribution of alleles in fig cultivars, series 1 is group $B$, series2 is group A more accurately and clearly. The high symmetry between Small Bokrati, Bokrati as well as F3 because they are likely to be a single cultivar. The distribution of cultivars in the similarity tree (Figure 21) was mainly related to the distribution of alleles. All fig cultivars which contain alleles 140, 170 bp at MFC2 locus were placed in the first group, as well as all cultivars which contain alleles $150 \mathrm{bp}$ at MFC2 locus were placed in the second group.

\section{CONCLUSION}

We have investigated 14 fig cultivars in southern Syria to determine the genetic relationship between them in order to identify their genetic identities and certify them in the ministry of agriculture as commercial cultivars. The conservation of genetic resources of figs, multiplication and breeding of masculine figs (caprifigs) such as F1 and F2 that greatly affect the quality of the fruits as paternity traits. The greater number of primers used in the study which helps for identification of the unique SSR alleles for characterization of fig trees in nurseries, and fields for purity assessment.

\section{REFERENCES}

Achtak, H., Oukabli, A., Ater, M., Santoni, S., Kjellberg, F., \& Khadari, B. (2009) Microsatellite markers as reliable tools for fig cultivar identification. Journal of the American Society for Horticultural Science, 134, 624-31. https://doi.org/10.21273/JASHS.134.6.624

Ahmed, B. A., Ghada, B., Laila, E., Hafid, A., Bouchaib, K., \& Amel, S. H. (2015) Use of morphological traits and microsatellite markers to characterize the Tunisian cultivated and wild figs (Ficus carica L.). Biochemical Systematics and Ecology, 59, 209-219. https://doi. org/10.1016/j.bse.2015.01.026

Akin, M., Poljuha, D., Eyduran, S. P., Weber, T., Özkan, G., \& Ercişli, S. (2020). Molecular characterization of fig (Ficus carica L.) germplasm from Northeastern Black sea region. Genetika. 52(2), 411-420. https://doi. org/10.2298/GENSR2002411A

Aksoy, U. (1998). Why fig? An old taste and a new perspective. Acta Horticulture, 480, 25-35. https://doi.org/10.17660/ ActaHortic.1998.480.1

Ali, S. H. (2019). Characterization of Microsatellite Loci in different Fig (Ficus carica L.) Landraces in Duhok and Erbil Provinces in Kurdistan RegionIraq. Zinc Journal of Pure and Applied Sciences 31(2), 48-56. https://doi. org/10.21271/ZJPAS.31.2.7

Annual Agricultural Statistical Group (2018) Ministry of Agriculture and Agrarian Reform Publications.

Aradhya, M. K., Stover, E., Velasco, D., \& Koehmstedt, A. (2010). Genetic structure and differentiation in cultivated fig (Ficus carica L.). Genetica, 138(6), 681-694. https://doi.org/10.1007/s10709-010-9442-3

Berg, C. C. (2003). Flora Malesiana precursor for the treatment of Moraceae 1. The main subdivision of Ficus. the subgenera, Blumea, 48.

Botstein, D., White, R. L., Skolnick, M., \& Davis, R. W. (1980). Construction of a genetic linkage map in man using restriction fragment length polymorphisms. American Journal of Human Genetics, 32(3), 314-331.

Boudchicha, R. H., Hormaza, J. I., \& Benbouza, H. (2018). Diversity analysis and genetic relationships among local Algerian fig cultivars (Ficus carica I.) using SSR markers. South African Journal of Botany, 116, 207 215. https://doi.org/10.1016/j.sajb.2018.03.015

Chatti, K., Baraket, G., Ben Abdelkrim, A., Saddoud, O., Mars, M., Trifi, M., \& Salhi Hannachi, A. (2010). Development of molecular tools for characterization and genetic diversity analysis in Tunisian fig (Ficus carica) cultivars. Biochemical genetics, 48(9-10), 789-806. https://doi. org/10.1007/s10528-010-9360-1

Costa, F., Marchese, A., Mafrica, R., Di Vaio, C., Ferrara, G., Fretto, S. Quartararo, A., Marra, F. P., Mennone, C., Vitale, F., Reale, S., \& Caruso, T. (2015, August) Genetic diversity of fig (Ficus carica L.) cultivars grown in Southern Italy revealed by the use of SSR markers. 
In V International Symposium on Fig 1173 (pp. 75-80).

Debbabi, O. S., Khanfir, E., Dridi, M. A., \& Mars, M. M. (2021). Ethnobotanical and on farm genetic surveys of fig (Ficus carica L.) genetic resources in Kerkennah islands. International Journal of Horticultural Science and Technology, 8(2), 153-163. 10.22059/ijhst.2020.310191.396

Di Gaspero, G., Peterlunge, E., Testolin, R., Edwards, K. J., \& Cipriani, G. (2000) Conservation of microsatellite loci within the genus Vitis. Theoretical and Applied Genetics, 101(1-2), 301-308. https://doi. org/10.1007/s001220051483

Dice, L. R. (1945). Measures of the amount of ecologic association between species. Ecology, 26, 297-302. https://doi.org/10.2307/1932409

Dowdeswell, E. (1995). The cooperative ethic of the biodiversity convention poses a great challenge for the vital Habitats and cultures of Mediterranean Mosaic. Diversity, 11(1\&2), 9-13.

Eoman, S., Ipek, M., Erturk, U., Tangu, N. A., Durgut, E., Barut, E., Ercisli, S., \& Ipek, A. (2017). Assessment of genetic relationship among male and female fig genotypes using simple sequence repeat (SSR) markers. Notulae Botanicae Horti Agrobotanici Cluj-Napoca, 45(1), 172178. https://doi.org/10.15835/nbha45110756

Erfani, J., Ebadi, A., Abdollahi, H., \& Fatahi, R. (2012). Genetic diversity of some pear cultivars and cultivars using simple sequence repeat (SSR) markers. Plant Molecular Biology Reporter, 30(5), 1065-1072. https://doi. org/10.1007/s11105-012-0421-y

Essid, A., Aljane, F., Ferchichi, A., \& Hormaza, J. I. (2015). Analysis of genetic diversity of Tunisian caprifig (Ficus carica L.) accessions using simple sequence repeat (SSR) markers. Hereditas, 152, 1. https://doi. org/10.1186/s41065-015-0002-9

Ganopoulos, I., Xanthopoulou, A., Molassiotis, A., Karagiannis, E., Moysiadis, T., Katsaris, P., Filippos, A., Athanasios, T., Kalivas, A., \& Madesis, P. (2015). Mediterranean basin Ficus carica L.: from genetic diversity and structure to authentication of a Protected Designation of Origin cultivar using microsatellite markers. Trees, 29(6), 1959-1971. https://doi.org/10.1007/s00468-015-1276-2

Giraldo, E., Viruel, M., Lopez-Corales, A., \& Hormaza, J. I. (2005). Characterization and cross-species transferability of microsatellites in the common fig (Ficus carica L.(. Journal of Horticultural Science and Biotechnology, 80, 217224. https://doi.org/10.1080/14620316.2005.11511920

Hammer, O., Harper, D. A. T., \& Ryan, P. D. (2001). PAST: Paleontological statistics software package for education and data analysis. Palaeontologia Electronica, 4, 9.

Hormaza, J. I. (2002). Molecular characterization and similarity relationships among apricot (Prunus armeniaca L.) cultivars using simple sequence repeats. Theoretical and Applied Genetics, 104, 321-328. https://doi. org/10.1007/s001220100684

Huang, X.Q., Borner, A., Roder, M. S., \& Ganal, M. W. (2002). Assessing genetic diversity of wheat (Triticum sativum L.) germplasm using microsatellite markers. Theoretical and Applied Genetics, 105, 699-707. https://doi.org/10.1007/s00122-002-0959-4
Hussein, A. E., \& Jubrael, J. M. (2020). SSR Markers in Genetic Diversity Assessment of Fig Ficus carica L. Populations in Kurdistan RegionIraq. Science Journal of University of Zakho, 8(4), 123-130. https://doi. org/10.25271/sjuoz.2020.8.4.758

Khadari, B., Hochu, I., Santoni, S., \& Kjellberg, F. (2001). Identification and characterazation of microsatellite loci in the common fig Ficus carica and representative species of the genus Ficus. Molcular Ecology Notes, 1(3), 191-193. https://doi.org/10.1046/j.1471-8278.2001.00072.x

Knap, T., Jakše, J., \& Bandelj, D. (2015). Novel microsatellite markers for common fig, Ficus carica L. In V International Symposium on Fig 1173 (pp. 87-92)

Lazar, I. (2010). Gel Analyzer, A freeware 1D gel electrophoresis mage analysis software. Retrived from http://www.gelanalyzer.com

Marcotuli, I., Mazzeo, A., Nigro, D., Giove, S. L., Giancaspro, A. Colasuonno, P., Prgomet, Ž., Prgomet, I., Tarantino, A., Ferrara, G. \& Gadaleta, A. (2019) Analysis of genetic diversity of Ficus carica L. (Moraceae) collection using simple sequence repeat (SSR) markers. Acta scientiarum Polonorum. Hortorum cultus = Ogrodnictwo, 18(4):93-109. https://doi.org/10.24326/asphc.2019.4.9

Millar, C. I., \& Westfall, R. D. (1992). Allozyme markers in forest genetic conservation. New Forests, 6, 347-371. https://doi.org/10.1007/ BF00120652

Peakall, R., \& Smouse, P. E. (2012). GenAlEx 6.5: genetic analysis in Excel. Population genetic software for teaching and research--an update. Bioinformatics, 28(19), 2537-2539. https://doi.org/10.1093/ bioinformatics/bts460

Perez-Jiménez, M., López, B., Dorado, G., Pujadas-Salvá, A., Guzmán, G., \& Hernandez, P. (2012). Analysis of genetic diversity of southern Spain fig tree (Ficus carica L.) and reference materials as a tool for breeding and conservation. Hereditas, 149(3), 108-113. https://doi. org/10.1111/j.1601-5223.2012.02154.x

Powell, W., Morgante, M., Andre, C., Hanafey, M., Vogel, J., Tingley, S., \& Rafalski A. (1996) The comparison of RFLP, RAPD, AFLP and SSR (microsatellite) markers for germplasm analysis. Molecular Breeding, 2, 225-238. https://doi.org/10.1007/BF00564200

Sadder, M. T., Alshomali, I., Ateyyeh, A., \& Musallam, A. (2021) Physiological and molecular responses for long term salinity stress in common fig (Ficus carica L.). Physiology and Molecular Biology of Plants, 27(1), 107-117. https://doi.org/10.1007/s12298-020-00921-z

Saddoud, O., Baraket, G., Chatti, K., Trifi, M., Marrakchi, M., Mars, M., \& Salhi-Hannachi, A, (2011), Using morfological characters and simple sequence repeat (SSR) markers to characterize Tunisian fig (Ficus carica L.) cultivars. Acta Biologica Cracoviensia, 53(2), 7-14. https://doi. org/10.2478/v10182-011-0019-y

Saddoud, O., Chatti, K., Salhi-Hannachi, A., Mars, M., Rhouma, A., Marrakchi, M., \& Trifi, M. (2007). Genetic diversity of Tunisian figs (Ficus carica L.) as revealed by nuclear microsatellites. Hereditas, 144(4), 149-157. https://doi.org/10.1111/j.2007.0018-0661.01967.x 